\title{
Isolation and Determination of Sulfides in Ti-bearing Ultra Low Carbon Steels
}

\author{
Shigeharu HINOTANI, Joh ENDO, ${ }^{1)}$ Toru TAKAYAMA, Naomitsu MIZUI and Yasuo INOKUMA ${ }^{1)}$ \\ Iron and Steel Research Laboratories, Sumitomo Metal Industries, Ltd., Fuso-cho, Amagasaki, Hyogo-ken, 660 Japan. \\ 1) Sumitomo Metal Technology, Ltd., Fuso-cho, Amagasaki, Hyogo-ken, 660 Japan.
}

(Received on April 30, 1993; accepted in final form on July 15, 1993)

\begin{abstract}
Bake hardening properties of Ti-bearing ultra low carbon steels are affected by the precipitation behavior of TiN, MnS, TiS and $\mathrm{Ti}_{4} \mathrm{C}_{2} \mathrm{~S}_{2}$. Thus the methods of isolation and determination of these precipitates have been developed and applied to the study on the precipitate change with reheating of the steels.

All precipitates, TiN, MnS, TiS and $\mathrm{Ti}_{4} \mathrm{C}_{2} \mathrm{~S}_{2}$ were extracted by MS electrolysis. TiN was extracted by $10 \%$ $(\mathrm{v} / \mathrm{v})$ bromine-methanol. $\mathrm{MnS}$ was isolated from the residues (extracted by $\mathrm{MS}$ electrolysis) by $50^{\circ} \mathrm{C} \mathrm{HCl}$ treatment. TiS in the $50^{\circ} \mathrm{C} \mathrm{HCl}$ treated residues was decomposed by $10 \%(\mathrm{~m} / \mathrm{v})$ iodine-methylacetate and $\mathrm{Ti}_{4} \mathrm{C}_{2} \mathrm{~S}_{2}$ remained. $\mathrm{Mn}, \mathrm{Ti}$ and $\mathrm{S}$ in the residues were determined directly by $\mathrm{X}$-ray fluorescence method. $\mathrm{N}$ was determined by neutral titration method. The determined compositions of precipitates except TiS almost corresponded with their stoichiometries. TiS was determined to $\mathrm{TiS}_{\mathbf{1 . 3}}$.

Whole nitrogen precipitated as TiN and the amount did not change with reheating temperatures between 950 and $1250^{\circ} \mathrm{C}$. Total amount of the sulfides such as $\mathrm{MnS}$, TiS and $\mathrm{Ti}_{4} \mathrm{C}_{2} \mathrm{~S}_{2}$ changed scarcely with reheating temperatures, but the amount of each sulfide changed largely. Precipitates in the steels reheated below $1050^{\circ} \mathrm{C}$ were mainly $\mathrm{Ti}_{4} \mathrm{C}_{2} \mathrm{~S}_{2}$. It decomposed and transformed into TiS and $\mathrm{MnS}$ with raising the reheating temperature, and decreased drastically at $1150^{\circ} \mathrm{C}$. The precipitates above $1150^{\circ} \mathrm{C}$ were mainly $\mathrm{MnS}$ and $\mathrm{TiS}$, and the fraction depended on the ratio of $\mathrm{Ti}$ to $\mathrm{Mn}$ concentration in the steels.
\end{abstract}

KEY WORDS: isolation; extraction; sulfide; carbosulfide; ultra low carbon steel; bake hardenable steel.

\section{Introduction}

Recently a Ti-bearing ultra low carbon steel has been developed and widely used for an automobile steel sheet as a bake hardenable steel sheet (BH-steel) because of its good cold formability and high strength. Generally a BH-steel has a small amount of carbon and nitrogen (a few ten ppm), and is controlled to retain a few ppm carbon in a soluble state by adding a suitable amount of $\mathrm{Ti}$ and by annealing at a suitable temperature. However the control of precipitation is not easy, because BH-steels have only small amount of $\mathrm{C}, \mathrm{N}$ and $\mathrm{Ti}$ and their precipitates are largely affected by heat treatment processes.

In a Ti-bearing ultra low carbon steel some sulfides such as $\mathrm{MnS}$, TiS and $\mathrm{Ti}_{4} \mathrm{C}_{2} \mathrm{~S}_{2}$ precipitate in addition to $\mathrm{TiC}$ and $\mathrm{TiN}$. Especially $\mathrm{Ti}$ carbosulfide, $\mathrm{Ti}_{4} \mathrm{C}_{2} \mathrm{~S}_{2}$ precipitating during reheating of slabs plays an important role to control the solute carbon atoms. The crystalline structure of $\mathrm{Ti}_{4} \mathrm{C}_{2} \mathrm{~S}_{2}$ was studied first by Kudielka and Rohde. ${ }^{1)}$ Liu et al. ${ }^{2)}$ identified a sulfide precipitating in Ti microalloyed steels to $\mathrm{Ti}_{4} \mathrm{C}_{2} \mathrm{~S}_{2}$ not $\mathrm{Ti}_{2} \mathrm{~S}$, by analytical electron microscopy, although both the diffraction patterns are nearly identical. Kawasaki et $a l .{ }^{3)}$ studied the effect of $\mathrm{Ti}_{4} \mathrm{C}_{2} \mathrm{~S}_{2}$ on the bake hardening properties in Ti-bearing ultra low carbon steels. Sulfides in the steels have been reported to precipitate as $\operatorname{Ti}_{x} \mathrm{~S}_{y}(x<y)$ in a higher temperature region of austenite and as $\mathrm{Ti}_{4} \mathrm{C}_{2} \mathrm{~S}_{2}$ in a lower temperature region. ${ }^{4,5}$

The previous studies have been done by using electron microscope or analytical electron microscope with emphasis on the thermodynamical stability of sulfides. ${ }^{6}$ ) However the amount of each sulfide has not been studied. The amount of each sulfide including $\mathrm{Ti}_{4} \mathrm{C}_{2} \mathrm{~S}_{2}$ is necessary to be examined in order to control the solute carbon atoms in BH-steels.

The Nonmetallic Inclusion Analysis Subcommittee of the Iron and Steel Analysis Committee of the Iron and Steel Institute of Japan has reported some recommended methods for the isolation and determination of sulfides in several steels after the joint research. ${ }^{7)}$ However the report does not present a method which shows the way to isolate Ti sulfides including $\mathrm{Ti}_{4} \mathrm{C}_{2} \mathrm{~S}_{2}$ and to determine their amounts.

Thus in the present study, we have investigated potentiostatic electrolysis methods and the subsequent chemical treatments to isolate each sulfide and to determine the composition and amount. The developed method was applied to the study on the sulfides precipitating in a series of Ti-bearing ultra low carbon steels. 


\section{Experimental Procedures}

\subsection{Experimental Materials}

Four Ti-bearing ultra low carbon steels were prepared by vacuum induction melting. After heating the ingots at $1200^{\circ} \mathrm{C}$, they were forged above $900^{\circ} \mathrm{C}$. Then they were heated up to $1250^{\circ} \mathrm{C}$ for a half hour and hot rolled into $6 \mathrm{~mm}$ thick plates at temperatures between 900 and $1000^{\circ} \mathrm{C}$ being followed by air cooling. The chemical compositions are listed in Table 1. Mn content was only varied in four levels. To simulate the reheating process of slabs, the plates were annealed at 1250, 1150,1050 and $950^{\circ} \mathrm{C}$ for one hour in $\mathrm{Ar}$ gas atmosphere, and quenched into water. Some plates were annealed at $1050^{\circ} \mathrm{C}$ after annealing at $1250^{\circ} \mathrm{C}$.

\subsection{Potentiostatic Electrolysis Method}

Extraction of the whole precipitates from the steel matrices was employed by means of potentiostatic electrolysis in which methanol containing $1 \%(\mathrm{~m} / \mathrm{v})$ salicylic acid, $4 \%(\mathrm{v} / \mathrm{v})$ methyl salicylate and $1 \%(\mathrm{~m} / \mathrm{v})$ tetramethylammonium chloride was used as an electrolyte (denoted as MS electrolysis below). ${ }^{8}$ A sample with the surface area of $0.0012 \mathrm{~m}^{2}$ was immersed into the MS electrolyte bubbled by $\mathrm{Ar}$ gas flow and was dissolved electrochemically at the current density of $200 \mathrm{~A} / \mathrm{m}^{2}$ until the weight loss of $0.5 \mathrm{~g}$. After the end of electrolysis the samples were ultrasonically vibrated in the electrolyte in order to strip the precipitates from the sample surfaces. The precipitates were collected by filtration using Nuclepore Filter of $25 \mathrm{~mm}$ diameter with pore size of $0.2 \mu \mathrm{m}$.

\subsection{Compositional Analysis of Precipitates}

Determination of $\mathrm{S}$ in the sulfides is generally employed by infrared absorption method after combustion in an induction (IR method) or by $\mathrm{H}_{2} \mathrm{~S}$ evolution-methylene blue spectrophotometric method. ${ }^{7}$ )

Because handling of the above methods is complicated, we have tried a X-ray fluorescence (XRF) method to determine $S$ directly using the precipitates collected on a filter. Since relationship between $\mathrm{S}-\mathrm{K} \alpha$ intensities and $\mathrm{S}$ amounts obtained by $\mathrm{H}_{2} \mathrm{~S}$ evolution-ethylene blue spectrophotometric method $\left(\mathrm{H}_{2} \mathrm{~S}\right.$ evolution method) shows good linearity as shown in Fig. 1, the XRF method is capable to determine $\mathrm{S}$ directly. Metallic elements in the precipitates can be determined simultaneously by the XRF method. The XRF analysis was performed by Simultix 3530 (Rigaku) with $\mathrm{Rh}$-target for fixed time of $20 \mathrm{sec}$.

\subsection{Grazing Incidence $X$-ray Diffraction}

A grazing incidence $\mathrm{X}$-ray diffraction method was used for the identification of precipitates, because the amount of collected precipitates on the filter was very small. The filter with the precipitates was stuck on a glass plate and $\mathrm{X}$-ray of $\mathrm{Co}-\mathrm{K} \alpha$ was irradiated at an incident angle of 1.0 degree.

\section{Procedures of Isolation and Determination}

\subsection{Determination of Total $S$ and Un-extracted $S$}

Total $\mathrm{S}$ in the steels was determined by the IR method. $S$ in the precipitates extracted by MS electrolysis was determined by XRF method. Un-extracted $S$ was defined as the difference between total $\mathrm{S}$ and $\mathrm{S}$ in the extracted precipitates.

\subsection{Isolation and Determination of TiN}

Steel chips of $5 \mathrm{~g}$ were dissolved by $10 \%(\mathrm{v} / \mathrm{v})$ bromine-methanol of $200 \mathrm{~m} l$ and the residues were filtrated on a membrane filter with $0.2 \mu \mathrm{m}$ pores. After the residues were decomposed by $20 \mathrm{~m} l \mathrm{H}_{2} \mathrm{SO}_{4}$ with $1 \mathrm{~g}$ copper sulfate (5-hydrate) and $10 \mathrm{~g}$ potassium sulfate, $\mathrm{N}$ was determined by neutral titration method following steam evaporation as ammonia. ${ }^{9)} \mathrm{Ti}$ in the residues was determined by XRF method.

\subsection{Isolation and Determination of Sulfides}

\subsection{1. $\mathrm{H}_{2} \mathrm{~S}$ Evolution Method}

An apparatus for $\mathrm{H}_{2} \mathrm{~S}$ evolution method is shown in Fig. 2. The precipitates extracted by MS electrolysis were transferred together with a Nucleopore filter to a decomposition flask in Fig. 2. $50 \mathrm{ml}$ washing solution prepared by mixing three volumes of $\mathrm{HCl}(1+60)$ with one volume of hydrazine dihydrochloride solution $(5 \mathrm{~g} / l)$ was transferred to a washing bottle. $50 \mathrm{ml}$ absorbing solution was transferred to an absorption flask. The absorbing solution was prepared by diluting $55 \mathrm{~g}$ zinc acetate (dihydrate) and $14 \mathrm{~g}$ sodium acetate (trihydrate) together with water until whole volume of $1000 \mathrm{ml}$.

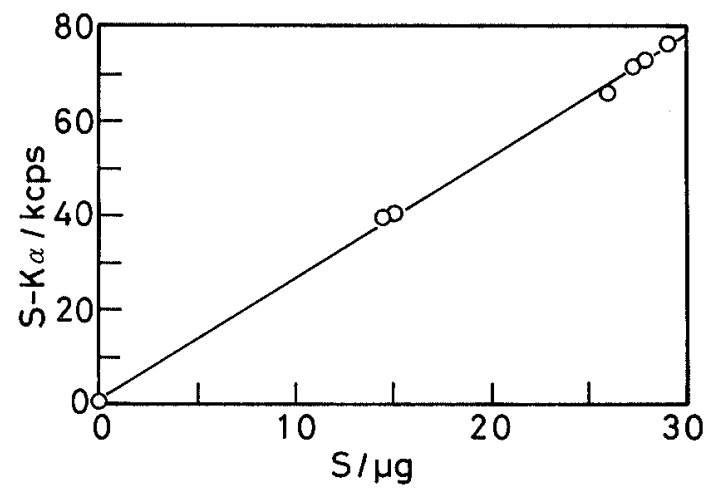

Fig. 1. Analytical curve for the determination of sulfur by $\mathrm{X}$-ray flourescence method.

Table 1. Chemical compositions of steels examined. (mass\%)

\begin{tabular}{ccccccccccc}
\hline Steel & $\mathrm{C}$ & $\mathrm{S}$ & $\mathrm{Si}$ & $\mathrm{Mn}$ & $\mathrm{P}$ & $\mathrm{Ti}$ & sol.Al & $\mathrm{N}$ & $\mathrm{O}$ \\
\hline Q1 & 0.0024 & 0.0065 & 0.001 & 0.06 & 0.008 & 0.045 & 0.041 & 0.0007 & 0.002 \\
Q2 & 0.0023 & 0.0067 & 0.002 & 0.18 & 0.008 & 0.044 & 0.041 & 0.0009 & 0.003 \\
Q3 & 0.0027 & 0.0067 & 0.002 & 0.34 & 0.008 & 0.046 & 0.039 & 0.0008 & 0.002 \\
Q4 & 0.0030 & 0.0064 & 0.003 & 0.72 & 0.007 & 0.044 & 0.042 & 0.0017 & 0.001 \\
\hline
\end{tabular}




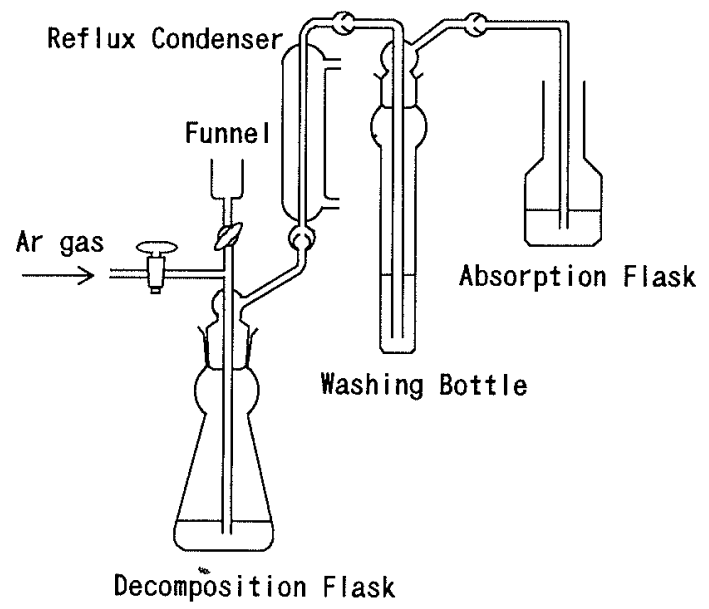

Fig. 2. Apparatus of $\mathrm{H}_{2} \mathrm{~S}$ evolution method.

After Ar gas purging, $50 \mathrm{~m} l \mathrm{HCl}$ was transferred to the decomposition flask through a funnel in a current of Ar gas of $100 \mathrm{~m} / / \mathrm{min}$ and the decomposition done for $30 \mathrm{~min}$. The decomposition behavior of $\mathrm{MnS}$, TiS and $\mathrm{Ti}_{4} \mathrm{C}_{2} \mathrm{~S}_{2}$ was investigated by heating $\mathrm{HCl}$ solution at $50^{\circ} \mathrm{C}$ and the boiling point. $\mathrm{H}_{2} \mathrm{~S}$ evolved by the decomposition of sulfides was absorbed by the absorbing solution and $\mathrm{S}$ in the solution was determined by ethylene blue spectrophotometric method. ${ }^{10)}$

\subsubsection{Halogen-Ester Method}

Isolation of Ti sulfides, $\mathrm{TiS}$ and $\mathrm{Ti}_{4} \mathrm{C}_{2} \mathrm{~S}_{2}$ was examined by using $10 \%(\mathrm{~m} / \mathrm{v})$ iodine-methylacetate, $10 \%(\mathrm{~m} / \mathrm{v})$ iodine-methanol or $10 \%(\mathrm{v} / \mathrm{v})$ bromine-methanol.

Filters collecting the precipitates were mounted again in a filtration apparatus and the halogen solution of $100 \mathrm{~m} l$ warmed at $60^{\circ} \mathrm{C}$ was poured slowly into the apparatus with taking $10 \mathrm{~min}$. After washing enough with methanol, $\mathrm{S}$ and $\mathrm{Ti}$ in the residues on the filter were determined by XRF method.

\section{Results and Discussion}

\subsection{Characterization of Precipitates by X-Ray Diffrac- tion}

The precipitates extracted by MS electrolysis were identified by grazing incidence X-ray diffraction. TiN was identified for whole samples. Peak intensities of TiS, $\mathrm{MnS}$ and $\mathrm{Ti}_{4} \mathrm{C}_{2} \mathrm{~S}_{2}$ changed with annealing temperatures and with steel compositions. The amounts of the sulfides were quasi-quantified by their peak intensities normalized by the peak intensity of TiN, because the amount of TiN did not change with annealing temperatures as discussed below.

The obtained fractions of sulfides changing with annealing temperatures are shown in Fig. 3 for steels $\mathrm{Q} 1(0.06$ mass $\% \mathrm{Mn})$ and Q4 $(0.72$ mass $\% \mathrm{Mn})$. The sulfide precipitating in steel Q1 annealed at $950^{\circ} \mathrm{C}$ was only $\mathrm{Ti}_{4} \mathrm{C}_{2} \mathrm{~S}_{2}$ and the fraction decreased with rising of annealing temperature. The fraction of TiS increased with annealing temperature and only TiS was detected in steel Q1 annealed at $1250^{\circ} \mathrm{C}$. $\mathrm{MnS}$ was not detected in steel Q1. On the other hand, both $\mathrm{Ti}_{4} \mathrm{C}_{2} \mathrm{~S}_{2}$ and $\mathrm{MnS}$ were detected in steel $\mathrm{Q} 4$ annealed at 950 and $1050^{\circ} \mathrm{C}$. Annealing the steel Q4 at 1150 and $1250^{\circ} \mathrm{C}$, only MnS

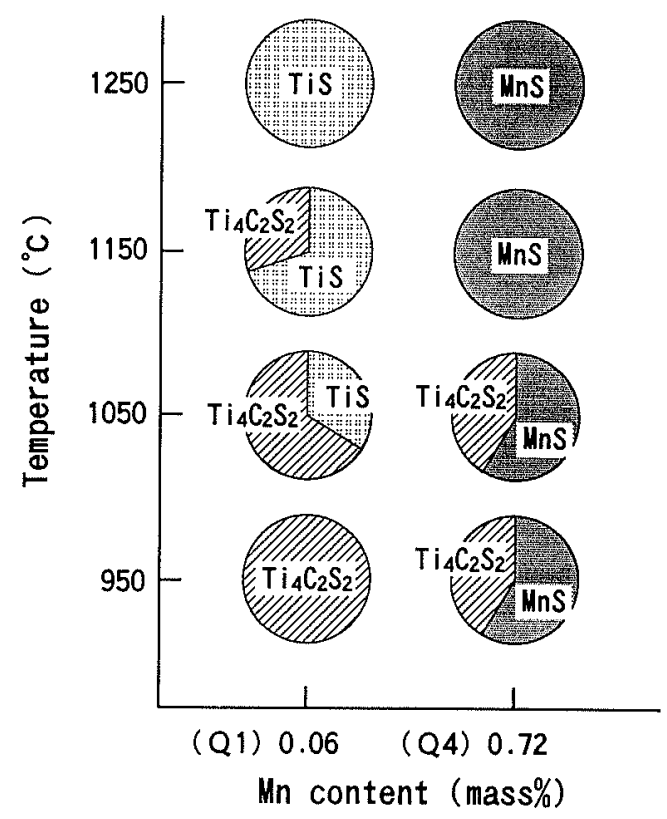

Fig. 3. Approximate fraction of sulfides determined by grazing incidence $\mathrm{X}$-ray diffraction.

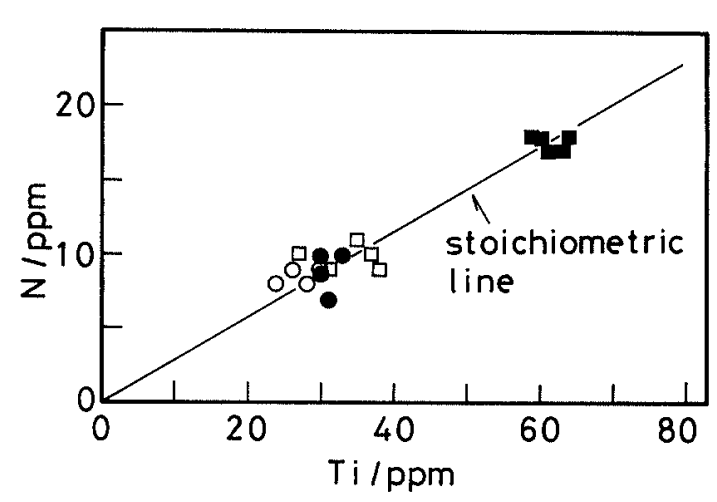

Fig. 4. Stoichiometric relationship between $\mathrm{Ti}$ and $\mathrm{N}$ in the precipitates extracted by $10 \%(\mathrm{v} / \mathrm{v})$ bromine-method. $\mathrm{O}: \mathrm{Q} 1, \mathbf{Q}: \mathrm{Q}, \square: \mathrm{Q}, \mathbf{\mathbf { m }}: \mathrm{Q} 4$

was detected.

\subsection{Isolation and Determination of TiN}

$\mathrm{Ti}$ and $\mathrm{N}$ in the residues extracted by brominemethanol method were determined by the procedures described in Sec. 3.2. The amounts of $\mathrm{N}$ in the residues approximately corresponded to total $\mathrm{N}$ in the steels and free $\mathrm{N}$ did not exist. The determined values of $\mathrm{Ti}$ and $\mathrm{N}$ in the residues are plotted in Fig. 4. Since they distributed nearly on the stoichiometric line of TiN, the residues were found to be TiN particles. The result was confirmed by the fact that $\mathrm{S}$ was not detected in the residues by XRF method. The amount of TiN changed scarcely with annealing temperatures as shown in Fig. 4.

\subsection{Determination of Precipitated $S$}

$S$ in the residues extracted by MS electrolysis was determined by XRF method for all steels annealed between 950 and $1250^{\circ} \mathrm{C}$. The result is shown as open circles in Fig. 5. The obtained values are slightly lower than total $\mathrm{S}$ in the steels determined by IR method as described in Sec. 3.1. Defining the differences between $S$ determined in the residues and total $S$ as un-extracted $S$, 


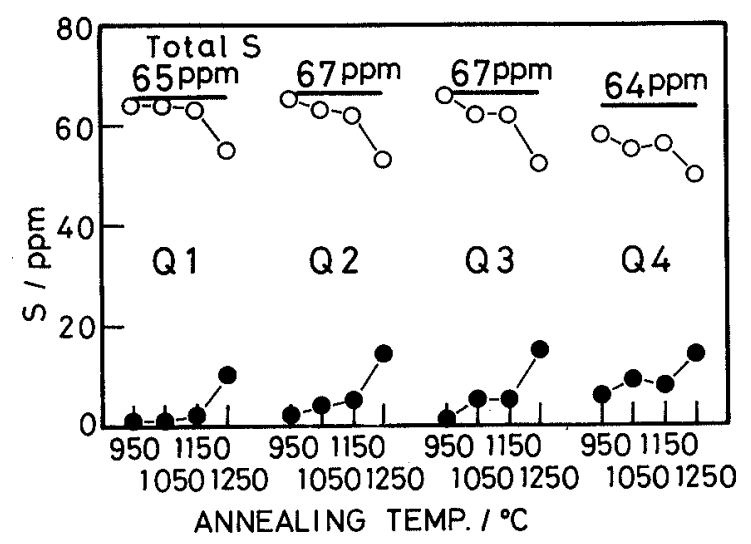

Fig. 5. Anneallng temperature variation of $S$ amounts in sulfides extracted by MS electrolysis. $O: S$ in extracted sulfides,

: un-extracted $\mathrm{S}$ (Total $\mathrm{S}-\mathrm{S}$ in extracted sulfides)

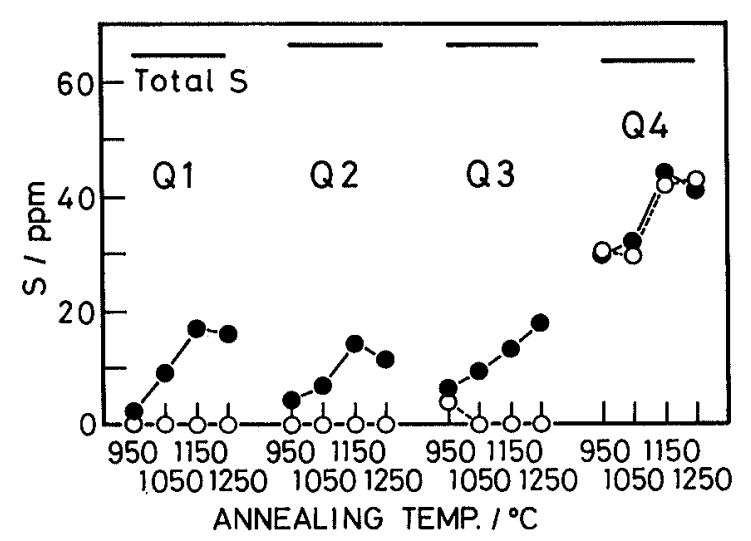

Fig. 6. Effect of $\mathrm{HCl}$ temperature on $\mathrm{S}$ amounts evolving as $\mathrm{H}_{2} \mathrm{~S}$.

$\mathrm{O}$ : evolution at $50^{\circ} \mathrm{C}$, evolution at boiling temperature

the values are plotted as solid circles in Fig. 5. The values of un-extracted $\mathrm{S}$ increase with annealing temperatures for all steels and are especially larger in steel Q4. Although the un-extracted $\mathrm{S}$ could be caused by leaking of tinny sulfide particles through the $0.2 \mu \mathrm{m}$ pores of Nucleopore filters, this cannot explain the behavior of un-extracted $\mathrm{S}$ with annealing temperatures. Considering that Liu and Jonas ${ }^{6}$ ) have reported the presence of solute sulpher of $7.5 \mathrm{ppm}(\mathrm{m} / \mathrm{m})$ in a $0.05 \mathrm{mass} \% \mathrm{Ti}$ low alloy steel annealed at $1260^{\circ} \mathrm{C}$, large fraction of the unextracted $\mathrm{S}$ is thought to be solute sulphur. However it was expressed as un-extracted $\mathrm{S}$, because solute sulpher was not examined.

\subsection{Isolation and Determination of $\mathrm{MnS}$}

As $\mathrm{MnS}$ is known to be decomposed with $\mathrm{H}_{2} \mathrm{~S}$ evolution by $\mathrm{HCl}$, the decomposition temperature was examined with $\mathrm{HCl}$ temperature of $50^{\circ} \mathrm{C}$ and the boiling point in order to isolate $\mathrm{MnS}$ from Ti-sulfides. Sulpher evolving as $\mathrm{H}_{2} \mathrm{~S}$ was determined by $\mathrm{H}_{2} \mathrm{~S}$ evolution method as described in Sec. 3.3.1.

The results examined at $\mathrm{HCl}$ temperatures of $50^{\circ} \mathrm{C}$ and boiling point are shown in Fig. 6. The determined values of $\mathrm{S}$ by $\mathrm{H}_{2} \mathrm{~S}$ evolution method with $50^{\circ} \mathrm{C} \mathrm{HCl}$ were zero for the steels Q1, Q2 and Q3 annealed at all temperatures

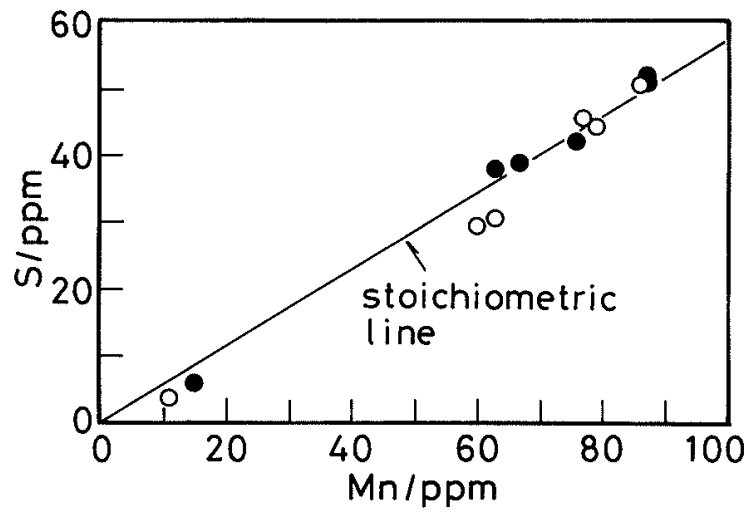

Fig. 7. Stoichiometric relationship between $\mathrm{S}$ and $\mathrm{Mn}$ in the residues treated by $50^{\circ} \mathrm{C} \mathrm{HCl}$ determined by $\mathrm{H}_{2} \mathrm{~S}$ evolution and XRF method.

$\mathrm{O}: \mathrm{H}_{2} \mathrm{~S}$ evolution method, $\mathrm{XRF}$ method

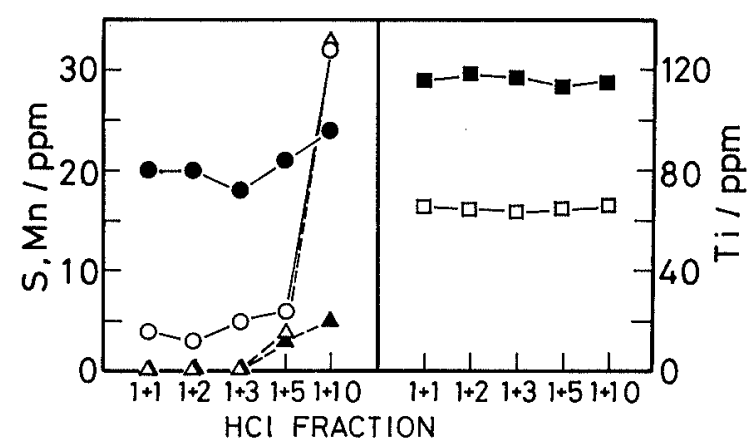

Fig. 8. Variation of $\mathrm{S}$ and $\mathrm{T} i$ in the residues with the fraction of $\mathrm{HCl}$ to water in the $\mathrm{HCl}$ treatment $(100 \mathrm{ml})$ at $50^{\circ} \mathrm{C}$ for the steel Q4 annealed at $1250^{\circ} \mathrm{C}$ (open) and $950^{\circ} \mathrm{C}$ (solid).

$\mathrm{O}: \mathrm{S}, \triangle: \mathrm{Mn}, \square: \mathrm{Ti}$

except for the steel Q3 annealed at $950^{\circ} \mathrm{C}$. This implies that $\mathrm{Ti}$ sulfides could not be decomposed by $50^{\circ} \mathrm{C} \mathrm{HCl}$, with considering the results by $\mathrm{X}$-ray diffraction in Fig. 3. While, certain values of $S$ were determined by boiled $\mathrm{HCl}$ for the steel $\mathrm{Q} 1$ which contained $\mathrm{Ti}$ sulfides at all annealing temperatures. Thus some fraction of $\mathrm{Ti}$ sulfides is thought to be decomposed by boiled $\mathrm{HCl}$. The determined values of $\mathrm{S}$ by $\mathrm{H}_{2} \mathrm{~S}$ evolution method with boiled $\mathrm{HCl}$ are nearly same with those determined by $50^{\circ} \mathrm{C} \mathrm{HCl}$ for the steel $\mathrm{Q} 4$ containing large amount of $\mathrm{MnS}$. These results suggest that only $\mathrm{MnS}$ is decomposed by $50^{\circ} \mathrm{C} \mathrm{HCl}$ and that $\mathrm{Ti}$ sulfides such as TiS and $\mathrm{Ti}_{4} \mathrm{C}_{2} \mathrm{~S}_{2}$ are not decomposed by $50^{\circ} \mathrm{C} \mathrm{HCl}$.

Figure 7 shows the relationship between $S$ determined by $\mathrm{H}_{2} \mathrm{~S}$ evolution method with $50^{\circ} \mathrm{C} \mathrm{HCl}$ and $\mathrm{Mn}$ determined by XRF method in the precipitates extracted by MS electrolysis for all the samples. Since these values distribute nearly on a stoichiometric line of $\mathrm{MnS}$ as shown in Fig. 7, it is confirmed that $\mathrm{MnS}$ can be isolated from TiS and $\mathrm{Ti}_{4} \mathrm{C}_{2} \mathrm{~S}_{2}$ by the treatment using $50^{\circ} \mathrm{C} \mathrm{HCl}$.

Because the procedure of $\mathrm{H}_{2} \mathrm{~S}$ evolution method is complicated, the determination of $\mathrm{S}$ in $\mathrm{MnS}$ by XRF method was tried. At first $\mathrm{S}$ and $\mathrm{Mn}$ in the residues extracted by MS electrolysis were determined by XRF method. The filter with the residues was mounted in the filtration apparatus and $\mathrm{HCl}$ solution of $100 \mathrm{ml}$ at $50^{\circ} \mathrm{C}$ was poured slowly. Then $\mathrm{S}, \mathrm{Mn}$ and $\mathrm{Ti}$ in the residues 
were determined again by XRF method. At the same time the effect of $\mathrm{HCl}$ concentration on the decomposition of $\mathrm{MnS}$ and Ti sulfides was examined. The aqueous solution of $\mathrm{HCl}$ was changed from $(1+1)$ to $(1+10)$ fraction.

The result was shown in Fig. 8. In both the samples of steel Q4 annealed at 950 and $1250^{\circ} \mathrm{C}, \mathrm{Mn}$ was detected in the residues treated by dilute $\mathrm{HCl}$ solution below $(1+3)$ fraction. This implies that dilute solution of $\mathrm{HCl}$ cannot decompose $\mathrm{MnS}$. While $\mathrm{S}$ in the residues is almost constant for $\mathrm{HCl}$ treatment with the higher fraction than $(1+3)$. The determined values of $\mathrm{Ti}$ in the residues are almost constant as shown in Fig. 8. These results suggest that $\mathrm{HCl}$ solution with $(1+3)$ fraction decomposes $\mathrm{MnS}$ enough and does not decompose $\mathrm{TiS}, \mathrm{Ti}_{4} \mathrm{C}_{2} \mathrm{~S}_{2}$ and $\mathrm{TiN}$. Therefore, when $\mathrm{S}$ and $\mathrm{Mn}$ in the residues are determined by XRF method before and after $\mathrm{HCl}(1+3)$ treatment at $50^{\circ} \mathrm{C}$, the differences for $\mathrm{S}$ and $\mathrm{Mn}$ should correspond to the stoichiometric values of $\mathrm{MnS}$. In fact, these values distribute near the stoichiometric line as shown in Fig. 7 (solid circles).

\subsection{Isolation of $\mathrm{TiS}$ and $\mathrm{Ti}_{4} \mathrm{C}_{2} \mathrm{~S}_{2}$}

Whole sulfides precipitating in the steels were decomposed by bromine-methanol. As $\mathrm{Ti}_{4} \mathrm{C}_{2} \mathrm{~S}_{2}$ was thought to be chemically stabler than TiS and $\mathrm{MnS}$, $\mathrm{Ti}_{4} \mathrm{C}_{2} \mathrm{~S}_{2}$ was tried to be isolated from TiS and $\mathrm{MnS}$ by using chemically weaker solutions than brominemethanol.

The precipitates extracted by MS electrolysis were treated by various halogen-methanol or halogen-ester solutions at $60^{\circ} \mathrm{C}$. Then $\mathrm{Ti}$ and $\mathrm{S}$ in the residues were determined by XRF method. The result for steel Q1 is shown in Fig. 9. The determined values of $\mathrm{Ti}$ in the residues without the treatment decreased with raising annealing temperature and corresponded to the change of TiS fraction with annealing temperature, because stoichiometric value of $\mathrm{Ti}$ against $\mathrm{S}$ in TiS is half of that in $\mathrm{Ti}_{4} \mathrm{C}_{2} \mathrm{~S}_{2}$.

When steel chips were directly treated by $10 \%(\mathrm{v} / \mathrm{v})$ bromine-methanol, the determined $\mathrm{Ti}$ values became small and $\mathrm{S}$ was not detected in all annealing temperature as shown in Fig. 9. The determined $\mathrm{Ti}$ values corresponded to those of TiN. While, when the residues

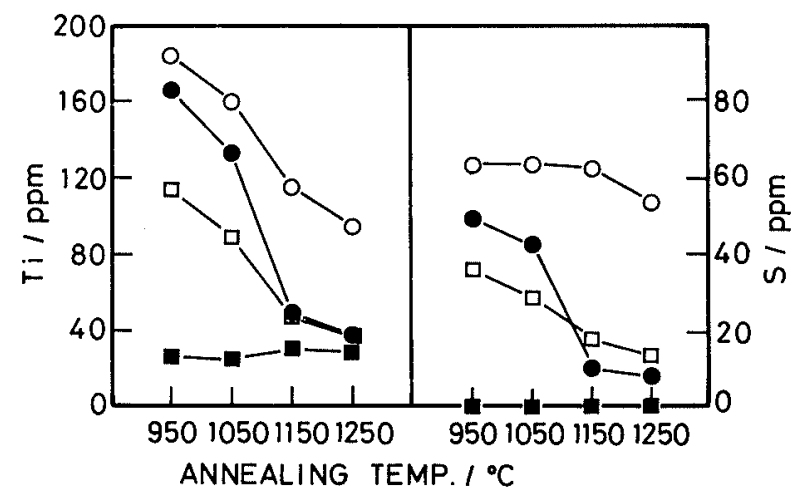

Fig. 9. $\mathrm{Ti}$ and $\mathrm{S}$ determined in the residues treated by various halogen-solution.

O: without treatment, $10 \%$ iodine-methylacetate $\square$ : $10 \%$ iodine-methanol, $\square: 10 \%$ bromine-methanol were treated by $10 \%(\mathrm{~m} / \mathrm{v})$ iodine-methylacetate or by $10 \%(\mathrm{~m} / \mathrm{v})$ iodine-methanol, both the determined $\mathrm{Ti}$ and $S$ decreased with raising annealing temperature. Especially, when the residues treated by $10 \%(\mathrm{~m} / \mathrm{v})$ iodine-methylacetate, the determined $\mathrm{Ti}$ value approached to that in the residues without the treatment at $950^{\circ} \mathrm{C}$ annealing and to that in the residues with bromine-methanol treatment at $1250^{\circ} \mathrm{C}$ annealing. The steel $\mathrm{Q} 1$ contained mainly $\mathrm{Ti}_{4} \mathrm{C}_{2} \mathrm{~S}_{2}$ at the annealing temperature of $950^{\circ} \mathrm{C}$ and mainly $\mathrm{TiS}$ at the annealing temperature of $1250^{\circ} \mathrm{C}$ as shown in Fig. 2. Therefore TiS in the residues extracted by MS electrolysis could be almost decomposed by $10 \%(\mathrm{~m} / \mathrm{v})$ iodine-methylacetate, and both TiN and $\mathrm{Ti}_{4} \mathrm{C}_{2} \mathrm{~S}_{2}$ could be remained without decomposition.

On the other hand, $\mathrm{S}$ was determined to relatively large values even in the residues treated by $10 \%(\mathrm{~m} / \mathrm{v})$ iodine-methylacetate at $1250^{\circ} \mathrm{C}$ annealing as shown in Fig. 9. The $\mathrm{S}$ value was larger than that estimated by the $\mathrm{Ti}$ value. When sulfides such as $\mathrm{TiS}$ and $\mathrm{Ti}_{2} \mathrm{~S}_{3}$ are decomposed by $\mathrm{HNO}_{3}$, free $\mathrm{S}$ is known to form. ${ }^{11)}$ Thus in the treatment of $10 \%(\mathrm{~m} / \mathrm{v})$ iodine-methylacetate, free $\mathrm{S}$ is thought to form. In fact the determined values of $\mathrm{S}$ in the residues by XRF method decreased with repeating of the measurement, because free $S$ is thought to sublime in the vacuum of XRF instrument.

The remaining of free $S$ on the filter was suppressed by increasing the volume of $10 \%(\mathrm{~m} / \mathrm{v})$ iodine-methylacetate as shown in Fig. 10. That is, the determined $\mathrm{S}$ value in the steel Q1 annealed at $1250^{\circ} \mathrm{C}$ was still large with the solution of $50 \mathrm{~m} l$ and it decreased to small amount with the solution above $100 \mathrm{~m} l$. While the $\mathrm{S}$ values in the steel Q1 annealed at $950^{\circ} \mathrm{C}$ did not change with the amount of the solution. Thus $\mathrm{Ti}_{4} \mathrm{C}_{2} \mathrm{~S}_{2}$ was not decomposed by the increase of solution. Therefore the isolation of TiS from $\mathrm{Ti}_{4} \mathrm{C}_{2} \mathrm{~S}_{2}$ was done by using $10 \%(\mathrm{~m} / \mathrm{v})$ iodine-methylacetate of $100 \mathrm{~m} l$ at $60^{\circ} \mathrm{C}$. Large amount of free $\mathrm{S}$ formed even by the treatment for the residues containing large amount of $\mathrm{MnS}$. Thus such residues were treated by $10 \%(\mathrm{~m} / \mathrm{v})$ iodine-methylacetate after $50^{\circ} \mathrm{C} \mathrm{HCl}(1+3)$ treatment.

Moreover, the decomposition of $\mathrm{TiS}$ by $10 \%(\mathrm{~m} / \mathrm{v})$ iodine-methylacetate was confirmed by X-ray diffraction for the residues before and after the treatment as shown in Fig. 11. The diffraction peaks of TiS disappeared by

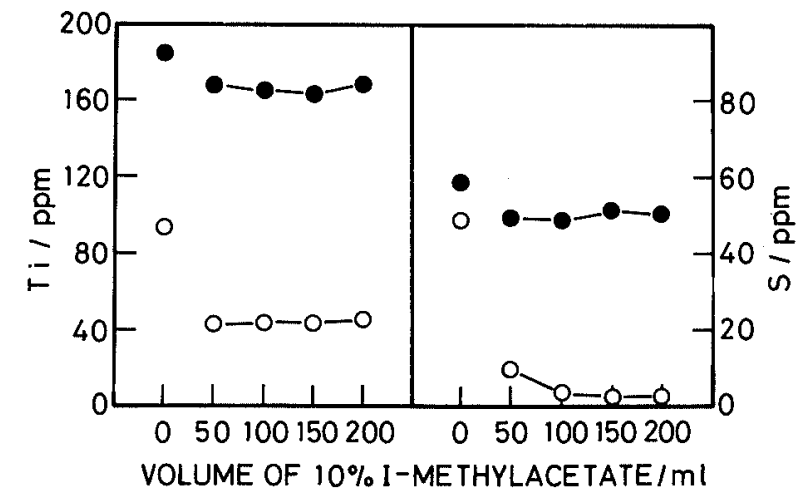

Fig. 10. Variation of $S$ and Ti with volume in $10 \%$ iodinemethylacetate treatment for the steel Q1 annealed at $1250^{\circ} \mathrm{C}(\mathrm{O})$ and $950^{\circ} \mathrm{C}(\mathrm{O})$. 


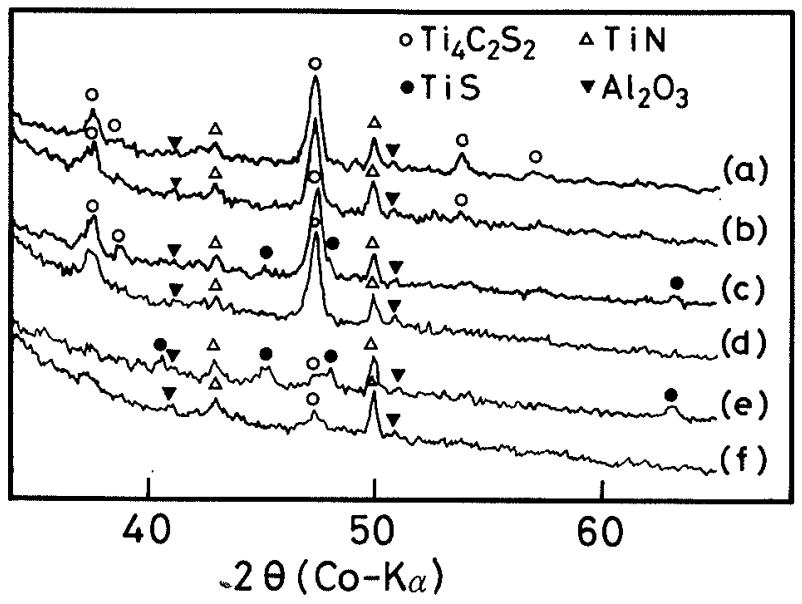

Fig. 11. X-ray diffraction patterns of extracted precipitates in the steel Q1 before and after $10 \%$ iodine-methylacetate.

(a), (c), (e): before treatment and (b), (d), (f): after treatment

(a), (b): annealed at $950^{\circ} \mathrm{C}$, (c), (d): annealed at $1050^{\circ} \mathrm{C}$, (e), (f): annealed at $1150^{\circ} \mathrm{C}$

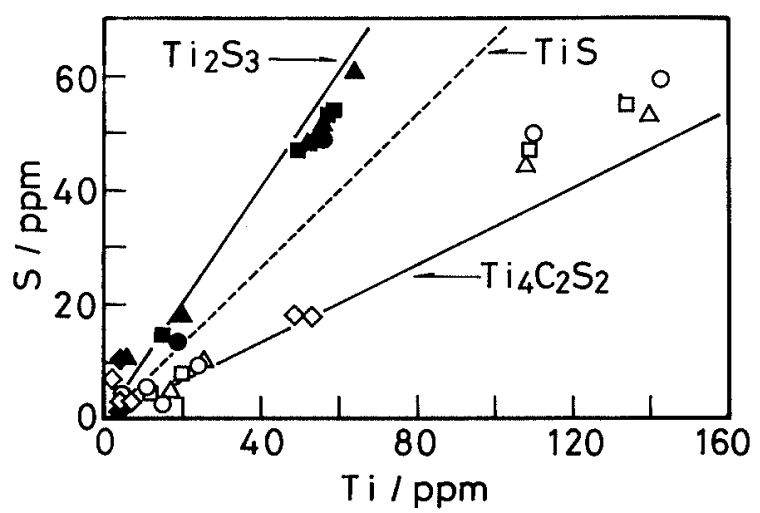

Fig. 12. Stoichiometric relationship between $S$ and Ti both in decomposition and in residues after $10 \%$ iodinemethylacetate treatment.

$\boldsymbol{\bullet}, \boldsymbol{\Delta}, \boldsymbol{\square}$, : decomposition for steels, Q1, Q2, Q3 and $\mathrm{Q} 4$ respectively, $O, \triangle, \square, \diamond:$ residues for steels, Q1, Q2, Q3 and Q4 respectively

the treatment of $10 \%(\mathrm{~m} / \mathrm{v})$ iodine-methylacetate. However the intensities of $\mathrm{Ti}_{4} \mathrm{C}_{2} \mathrm{~S}_{2}$ changed scarcely with the treatment.

\subsection{Determination of $\mathrm{TiS}$ and $\mathrm{Ti}_{4} \mathrm{C}_{2} \mathrm{~S}_{2}$}

The values of $\mathrm{S}$ and $\mathrm{Ti}$ in TiS which was isolated by $10 \%(\mathrm{~m} / \mathrm{v})$ iodine-methylacetate are plotted in Fig. 12. They distribute rather near the stoichiometric line of $\mathrm{Ti}_{2} \mathrm{~S}_{3}$ than that of TiS. The average ratio of $\mathrm{S}$ to $\mathrm{Ti}$ was 1.3. Sanagi et al. ${ }^{4)}$ have reported that $\mathrm{Ti}_{x} \mathrm{~S}_{y}(x<y)$ precipitates at the annealing temperature $1250^{\circ} \mathrm{C}$. Okamoto and Mizui ${ }^{5}$ have also reported that the ratio of $\mathrm{Ti}$ to $\mathrm{S}$ in $\mathrm{Ti}$ sulfide precipitating in low Mn steels was $45 / 55$. Although our result was in agreement with their reports, X-ray diffraction or electron diffraction could not identify those sulfides.

On the other hand, the determined values of $\mathrm{S}$ and $\mathrm{Ti}$ in $\mathrm{Ti}_{4} \mathrm{C}_{2} \mathrm{~S}_{2}$ distribute almost near the stoichiometric line of $\mathrm{Ti}_{4} \mathrm{C}_{2} \mathrm{~S}_{2}$ as shown in Fig. 12. However the values of $\mathrm{S}$ distribute somewhat higher than the line for the samples

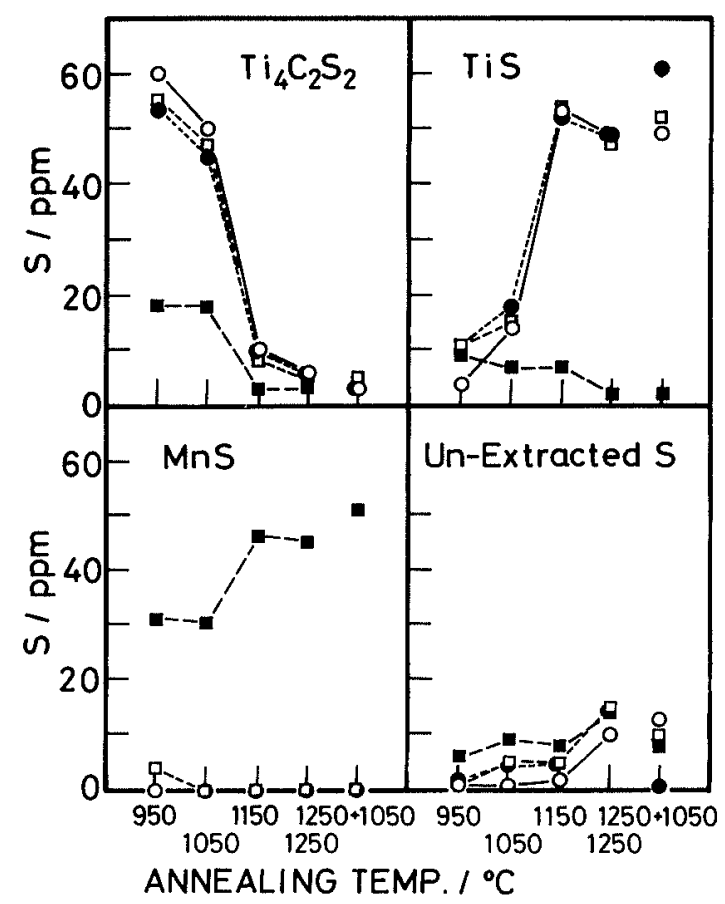

Fig. 13. Effect of annealing temperature on the amounts of $\mathrm{Ti}_{4} \mathrm{C}_{2} \mathrm{~S}_{2}, \mathrm{TiS}, \mathrm{MnS}$ and un-extracted $\mathrm{S}$ in the steels examined.

O: Q1, : Q2, $\square:$ Q3, $\mathbf{\square}:$ Q4

containing larger amount of $\mathrm{Ti}_{4} \mathrm{C}_{2} \mathrm{~S}_{2}$. It was thought to be caused by the co-precipitation of $\mathrm{Ti}_{4} \mathrm{C}_{2} \mathrm{~S}_{2}$ with $\mathrm{TiS},{ }^{12,13)}$ the presence was not examined.

\subsection{Precipitation Behavior of Sulfides}

The above developed methods for the isolation and determination of sulfides were applied to the study on the precipitate change with reheating of Ti-bearing ultra low carbon steels.

The obtained amount of each sulfide, $\mathrm{MnS}, \mathrm{TiS}\left[\mathrm{Ti}_{x} \mathrm{~S}_{y}\right.$ $(x<y)]$ or $\mathrm{Ti}_{4} \mathrm{C}_{2} \mathrm{~S}_{2}$ was expressed by $\mathrm{S}$ concentration in the steels as shown in Fig. 13. The precipitation behavior of sulfides with annealing temperatures was almost similar in the steels Q1, Q2 and Q3 of which Mn concentrations were from 0.06 to 0.34 mass $\%$. The sulfides precipitating in those steels were mainly $\mathrm{Ti}_{4} \mathrm{C}_{2} \mathrm{~S}_{2}$ and TiS. The amount of $\mathrm{Ti}_{4} \mathrm{C}_{2} \mathrm{~S}_{2}$ decreased and that of TiS increased drastically at $1150^{\circ} \mathrm{C}$ as shown in Fig. 13 . This implies that $\mathrm{Ti}_{4} \mathrm{C}_{2} \mathrm{~S}_{2}$ transforms into TiS at the temperature between 1050 and $1150^{\circ} \mathrm{C}$, because the total amount of sulfides remained almost constant at whole annealing temperatures.

On the other hand, the sulfides precipitating in the steel Q4 containing higher $\mathrm{Mn}$ concentration ( 0.72 mass $\%$ ) were mainly MnS and $\mathrm{Ti}_{4} \mathrm{C}_{2} \mathrm{~S}_{2}$ as shown in Fig. 13. In the steel $\mathrm{Ti}_{4} \mathrm{C}_{2} \mathrm{~S}_{2}$ transformed into $\mathrm{MnS}$ with the decomposition at the annealing temperature between 1050 and $1150^{\circ} \mathrm{C}$.

The precipitation behaviors of $\mathrm{Ti}_{4} \mathrm{C}_{2} \mathrm{~S}_{2}$ and $\mathrm{MnS}$ are in good agreement with the thermodynamical calculation by Liu and Jonas. ${ }^{6)}$ The slight increase of un-extracted $\mathrm{S}$ with raising annealing temperature implies that small amounts of solute $\mathrm{S}$ form at the higher annealing temperatures of whole steels examined. 


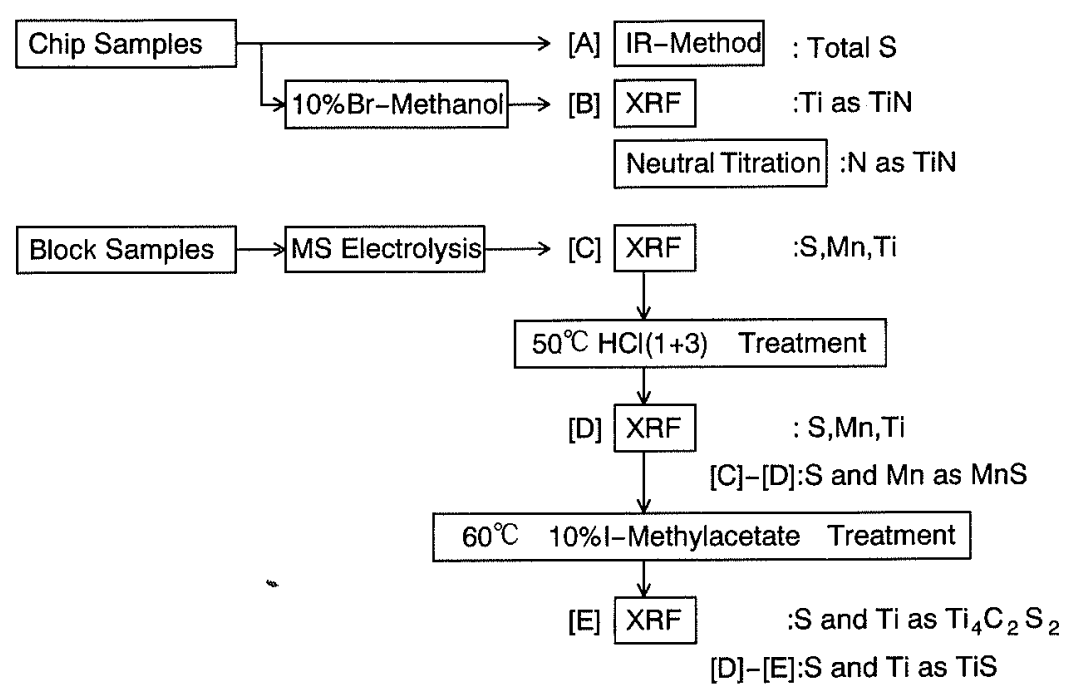

Fig. 14.

Flow chart of developed methods for isolation and determination of sulfides.
In Fig. 13, it is noted that the sulfide precipitations in the steels annealed at $1050^{\circ} \mathrm{C}$ after $1250^{\circ} \mathrm{C}$ annealing do not show any change comparing with those annealed at $1250^{\circ} \mathrm{C}$. Because the sample was re-annealed at lower temperature than that of drastic transformation of $\mathrm{Ti}_{4} \mathrm{C}_{2} \mathrm{~S}_{2}$ to $\mathrm{TiS}$ or $\mathrm{MnS}, \mathrm{Ti}_{4} \mathrm{C}_{2} \mathrm{~S}_{2}$ is thought not to precipitate in the short annealing time of $1 \mathrm{~h}$.

\section{Conclusion}

The methods of isolation and determination of TiN, $\mathrm{MnS}$, TiS and $\mathrm{Ti}_{4} \mathrm{C}_{2} \mathrm{~S}_{2}$ precipitating in Ti-bearing ultra low carbon steels have been developed and applied to the study on the precipitation behavior in reheating process of the steels. The results obtained are as follows:

(1) The procedures of developed methods are summarized in Fig. 14. All precipitates, TiN, MnS, TiS and $\mathrm{Ti}_{4} \mathrm{C}_{2} \mathrm{~S}_{2}$ were extracted by $\mathrm{MS}$ electrolysis. TiN was extracted by $10 \%(\mathrm{v} / \mathrm{v})$ bromine-methanol. $\mathrm{MnS}$ was isolated from the residues (extracted by MS electrolysis) by $50^{\circ} \mathrm{C} \mathrm{HCl}$ treatment, because only $\mathrm{MnS}$ was decomposed with $\mathrm{H}_{2} \mathrm{~S}$ evolution. TiS was isolated from the $50^{\circ} \mathrm{C} \mathrm{HCl}$ treated residues by $10 \%(\mathrm{~m} / \mathrm{v})$ iodinemethylacetate, because TiS was decomposed by the solution and $\mathrm{Ti}_{4} \mathrm{C}_{2} \mathrm{~S}_{2}$ remained.

(2) $\mathrm{Mn}, \mathrm{Ti}$ and $\mathrm{S}$ in the residues on extraction filters were determined directly by X-ray fluorescence method. $\mathrm{N}$ was determined by neutral titration method. The determined compositions of precipitates except TiS almost corresponded with their stoichiometries. TiS was determined to $\mathrm{TiS}_{1.3}$.
(3) Whole nitrogen precipitated as TiN and the amount did not change with reheating temperatures between 950 and $1250^{\circ} \mathrm{C}$. Total amount of the sulfides such as $\mathrm{MnS}$, TiS and $\mathrm{Ti}_{4} \mathrm{C}_{2} \mathrm{~S}_{2}$ changed scarcely with reheating temperatures, but the amount of each sulfide changed largely. The precipitates in the steels reheated below $1050^{\circ} \mathrm{C}$ were mainly $\mathrm{Ti}_{4} \mathrm{C}_{2} \mathrm{~S}_{2}$. It decomposed and transformed into $\mathrm{TiS}$ and $\mathrm{MnS}$ with raising the temperature, and decreased drastically at $1150^{\circ} \mathrm{C}$. The precipitates in the steels reheated above $1150^{\circ} \mathrm{C}$ were mainly $\mathrm{MnS}$ and TiS, and the fraction depended on the ratio of $\mathrm{Ti}$ to $\mathrm{Mn}$ concentration in the steels.

\section{REFERENCES}

1) H. Kudielka and H. Rohde: Z. Krist., 114 (1960), 447.

2) W. J. Lui, S. Yue and J. J. Jonas: Metall, Trans., 20A(1989), 1907.

3) K. Kawasaki, S. Sanagi, T. Senuma, S. Akamatsu, N. Yoshinaga and O. Akisue: Tetsu-to-Hagané, 79 (1993), 76.

4) S. Sanagi, K. Kawasaki and T. Kawano: CAMP-ISIJ, 2 (1989), 2015.

5) A. Okamoto and N. Mizui: Tetsu-to-Hagané, 76 (1990), 422.

6) W. J. Liu and J. J. Jonas: Metall, Trans., 20A (1989), 1361.

7) K. Narita: Tetsu-to-Hagané, 73 (1987), 67.

8) T. Suzuki, S. Watanabe, O. Yasuda and H. Sato: Tetsu-to-Hagané, 64 (1978), S368.

9) JIS G 1128-1980

10) I. Inamoto and T. Otsuki: Tetsu-to-Hagané, 66 (1980), S398.

11) T. Chitani: Inorganic Chemistry, Vol. II, 427, Sangyo-tosho, (1959).

12) N. Yoshinaga, K. Ushioda, S. Akamatsu and O. Akisue: ISIJ Int., 34 (1994), 24.

13) S. Hamanaka, T. Ichioka, T. Kasahara, T. Yamada and H. Kimura: Physical Metallurgy of IF Steels, ed. by Res. Comm. on Ultra Low Carbon Sheet Steels, ISIJ, Tokyo, (1993), 62. 